Article

\title{
Political Interest among European Youth with and without an Immigrant Background
}

\author{
Oshrat Hochman ${ }^{1, *}$ and Gema García-Albacete ${ }^{2}$ \\ ${ }^{1}$ GESIS-Leibniz Institute for the Social Sciences, 68159 Mannheim, Germany; E-Mail: oshrat.hochman@gesis.org \\ 2 Department of Social Sciences, Universidad Carlos III de Madrid, 28903 Madrid, Spain; E-Mail: gemgarci@clio.uc3m.es \\ * Corresponding author
}

Submitted: 28 June 2019 | Accepted: 19 November 2019 | Published: 27 December 2019

\begin{abstract}
Our article investigates political engagement among youth with and without an immigration background. Tapping to current debates on intergenerational assimilation processes in Europe, we look at differences in levels of political interest between immigrants, children of immigrants and natives. In particular, we argue that such differences are a function of respondents' identification with the receiving society. We predict that among respondents with an immigrant background higher levels of national identification will be positively correlated with political interest. Among natives, political interest will not depend on levels of national identification. These expectations reflect the ideas of the social identity perspective according to which group identification increases adherence to group norms and adherence to norms is stronger among individuals who suffer from identity uncertainty. We test our model in four European countries: England, Germany, the Netherlands, and Sweden, using data from the CILS4EU project. Our findings indicate that interest in the politics of the survey country differs between respondents with and without an immigrant background. Respondents with an immigrant background who also have a strong national identification are more likely to report a political interest than natives. Respondents with an immigrant background who have a low national identification, are less likely to report a political interest than natives. The findings also reveal that political discussions at home and associationism positively predict political interest whereas girls show significantly lower odds to be politically interested.
\end{abstract}

\section{Keywords}

assimilation; CILS4EU project; immigrant background; national identification; political interest; youth

\section{Issue}

This article is part of the issue "Immigration from the Migrants' Perspective" edited by Alice Ramos (Institute of Social Sciences, Portugal), Eldad Davidov (University of Cologne, Germany/University of Zurich, Switzerland), Peter Schmidt (University of Giessen, Germany), Marta Vilar Rosales (Institute of Social Sciences, Portugal) and Dina Maskileyson (University of Cologne, Germany).

(C) 2019 by the authors; licensee Cogitatio (Lisbon, Portugal). This article is licensed under a Creative Commons Attribution 4.0 International License (CC BY).

\section{Introduction}

Political interest indicates "the degree to which politics arouses a citizen's curiosity" (van Deth, 1990, p. 278). It is often understood as one of the main determinants of political participation (Milbrath, 1965, p. 40; Verba, Schlozman, \& Brady, 1995, p. 334), also for young people (García-Albacete, 2014), and as a prerequisite for an active and democratic citizenry (i.e., van Deth \& Elff, 2004, p. 478). Whether young people de- velop political interest or not is particularly critical for their future as active (or inactive) citizens. Political interest has been found to develop during young adulthood, particularly during the so-called "formative years" (Kinder \& Sears, 1985; Verba et al., 1995) and to be remarkably stable over the lifespan (Neundorf, Smets, \& García-Albacete, 2013). For that reason, adolescence and young adulthood are key periods to study political interest. Corroborating the relevance of this period, previous research indicates that individuals who develop 
a taste for politics in adolescence will be more politically engaged in adulthood (Greco Morasso, 2012; Prior, 2010). Active political engagement, at the same time, can be understood as an important civic norm in democracy and a central quality of citizens' ideal of "good citizen" (van Deth, 2009).

Despite its relevance as an indication of social integration and a future active citizenry, the development of interest in politics among young people with an immigrant background has rarely been examined. One exception in this regard is the PIDOP project, in which Kim and Amnâ (2015) for example, compared Iraqi and Kurdish immigrants and natives in Sweden. Using a small and non-random sample ( $N=538$ ) of young adults aged 16 to 26 years, the authors find no differences between the two immigrant groups and the natives (Kim \& Amnâ, 2015, p. 257). Fernandes-Jesus, Malafaia, Ribeiro, and Menezes (2015) compared Portuguese natives and Brazilian and Angolan immigrants in Portugal. With a slightly larger yet non-random sample, they report that Portuguese youth shows a significantly higher interest in politics compared with the two migrant groups.

In the current study, we too focus on political interest. Complementing existing work, we investigate the emergence of interest in the politics of the "receiving" country in particular and estimate differences between natives and immigrants as well as differences between natives and children of immigrants, thus exploring political assimilation trends. Following Alba and Nee (1997) we define assimilation as "the decline and at its endpoint the disappearance, of an ethnic/racial distinction and the cultural and social differences that express it" (Alba \& Nee, 1997, p. 863). In addition, we test whether differences in political interest are moderated by levels of national identification.

In our investigation, we also control for respondents' friendship and language preferences as well as additional factors associated with immigrants' assimilation. Following political behavior theories, we further include several predictors of political interest in the analysis. Parental transmission, that is, the frequency of political talk within the family while an individual was a child, has been repeatedly found to be among the most important predictors of political interest (Neundorf et al., 2013; Prior, 2010; Terriquez \& Kwon, 2015). Parents influence their children's political engagement both through their social status, and their interest, engagement and participation style (Jennings, Stoker, \& Bowers, 2009). Jennings et al. (2009) further show that growing up in a politicized family, in which politics is often discussed, is also a good predictor of an early development of political interest as well as other political orientations. Not only the parents but also peers, the school, and other institutions contribute to the political engagement of youth (Quintelier, 2015). The contribution of peers to political engagement is particularly large among young people who have not developed a political interest at home (García-Albacete, 2013; Neundorf, Niemi, \& Smets, 2016).
The relationship between national identification and political interest has thus far gained surprisingly limited attention from immigration research (Hindriks, Verkuyten, \& Coenders, 2017). One reason for this lacuna is surely the fact that the causal relations between the two concepts are difficult to disentangle. In this article, we do not attempt to solve this debate. Relying on the Social Identity Theory (SIT), we maintain instead that identification shapes political interest and not the other way around. Specifically, we contend that national identification shapes the probabilities of immigrants and children of immigrants to express interest in politics and moderates the effect of having an immigrant background on political interest. Analytically, we are however unable to exclude the possibility of reversed causality.

Our study makes the following contributions: (1) we investigate differences between natives and immigrants, as well as between natives and children of immigrants, utilizing data from four different European countries. Pooling these countries together we have sufficient data to estimate logistic regression models for this purpose, with a wide set of control variables; (2) to avoid mixing interest in the politics of the receiving society with interest in the politics of a respective country of origin, we focus specifically on the former; (3) referring to the SIT we propose a mechanism that may clarify the emergence of differences in political interest between natives, immigrants and children of immigrants. Specifically, we test for a moderation of national identification in the relations between immigrant status and political interest.

\section{Theoretical Framework}

\subsection{Political Engagement: An Intergenerational Assimilation Process?}

Since very early on, researchers maintained that assimilation is an intergenerational process (e.g., Gans, 1979; Liberson, 1973). However, while some scholars maintain that assimilation increases over generations (Alba \& Nee, 1997; Gans, 1992), others are of the opinion that this is not necessarily the case (e.g., Zhou, 1997). Indeed, proponents of the segmented assimilation theory in North America showed that children of immigrants are unable to narrow the structural gap with peers who are not children of immigrants. They also report that in some immigrant groups, the offspring often hold on to their cultural heritage and ethnic identification (Portes \& Rumbaut, 2001). Studies on assimilation in Europe to the most part failed to indicate a process of segmented assimilation and seem to support the idea that assimilation intensifies over generations (see, e.g., Diehl \& Schnell, 2006; Hochman, 2010; Kalter, 2018).

In line with the classic assimilation theory, previous studies report that among immigrants, the longer they stay in the receiving society, the stronger is their political engagement (Bass \& Casper, 2001; Messina, 2006; 
White, Nevitte, Blais, Fournier, \& Gidengil, 2006). Looking at electoral behavior, Ramakrishnan and Espenshade (2001) find a similar pattern, with the exception of Latinos, in most other migrant minorities in the USA comparing immigrants and immigrant descendants. Bevelander and Pendakur (2011) report the same for Sweden. Lien (2004) also studied generational differences in voting participation among immigrant minorities in the US. She reports an altogether different picture according to which being foreign-born is not associated with lower voting probabilities among registered (eligible) individuals. However, the need for registering is a known source of inequality in elections, which would point to the role of resources (and not motivations) in casting a vote. These and other studies stress differences not only between individuals with an immigrant background and without, but also between immigrants and immigrant offspring or children of immigrants (e.g., Monforte \& Morales, 2018). In our own study we thus look at three groups: natives (individuals without an immigrant background), immigrants (who are foreignborn), and children of immigrants.

\subsection{National Identification as a Key Factor for Young Immigrants' Political Assimilation}

National identification is a form of social identification that is identification with a specific social group. According to the SIT, individuals identify with a social group to secure a positive self-concept (e.g., Tajfel, 1974). Social identity is based on processes of selfcategorization, evaluation, and identification. Our interest in national identification derives not only from its importance as a meaningful dimension of assimilation. Identification processes have generally been known to intensify in adolescence (e.g., Erikson, 1968). In this period, individuals are more engaged in reflections on who they are, which in turn helps them realize their agency as individuals, and develop tools to cope in the social world (Phinney, 1990; Schwartz, Coté, \& Jensen Arnett, 2005).

The social identity perspective maintains that ingroup-identification increases individuals' motivation to act in the name of this group (Huddy, 2001; Turner, 1999). The self-categorization theory specifically stresses that self-categorization involves the comparison of the self to the prototype of the respective ingroup and accentuates perceived prototypical similarity between self and ingroup, which prescribes the behavior of the groups' members (Hogg, Hardie, \& Reynolds, 1995). Accordingly, Simon and Klandermans (2001) stress that collective identification is associated with selfstereotyping and conformity processes. Identification with any social group is therefore associated with higher congruence with its norms, orientations, values and beliefs (Klandermans, 2014). In the context of political interest, we thus assume that stronger national identification implies a stronger need to adhere to the group's norms (Hogg \& Reid, 2006). Interest in the politics of the na- tional group can be understood as a demonstration of such compliance and adherence.

Interestingly, Hogg et al. (1995) maintain that the need to comply with the ingroup's norms depends on how prototypical and uncertain individuals feel about their membership in that ingroup (see also Hogg, Adelman, \& Blagg, 2010). Given their position inbetween the heritage and the receiving society, individuals with an immigrant background (hereafter IIBs) are likely to feel more uncertain about their membership in the national majority compared with natives. For this reason, we predict that IIBs will be more interested in the politics of their receiving society the stronger their national identification is. This idea echoes the work of Simon et al. (1998) who maintain that political participation is sometimes used to fulfil identity needs (see also Klandermans, van der Toorn, \& van Stekelenburg, 2008). In light of these theoretical considerations, in what follows we will test the following hypotheses:

H1: Immigrants will show a lower interest in politics compared with natives;

H2: Children of immigrants will show lower interest in politics compared with natives, however, differences between these groups will be smaller compared to the difference found between immigrants and natives;

H3: Among IIBs, the stronger they identify with the survey country, the more likely they will be to be interested in this country's politics.

\section{Data, Variables, Analysis}

We use data from the CILS4EU project (Kalter et al., 2017) collected eight to nine years ago. On the one hand, this data may be somewhat outdated. On the other hand, we are unaware of more recent publicly available data which focuses on young IIBs in Europe from a cross-national perspective that has a similar quality and asks directly about interest in the politics of the receiving society. Most of the variables we use were collected during the second wave of the project (2011-2012) when the mean age of the respondents was about 16 (standard deviation 0.66). In addition, we reach back to the first wave (2010 and 2011) to include respondents' subjective perceptions of discrimination and their country of origin. We also use parents' information for some robustness checks, as described below. The dependent variable in our analysis is interest in the politics of the survey country, measured as: 1 "quite a lot, a lot, or very much interested" and 0 "a little, very little, or not at all interested." We recoded the original 5 points scale of this variable because it was skewed with about $55 \%$ of the respondents reporting being very little or not at all interested or a little interested.

This standard indicator of political interest used in surveys has been criticized for imposing a specific view 
of what politics is, mainly related to the electoral process and representative institutions, and therefore for being biased towards adults (i.e., O'Toole, Lister, Marsh, Jones, \& McDonagh, 2003) and towards men's interest (Ferrín, Fraile, García-Albacete, \& Gómez, 2019). The result being that it would underestimate young people's and women's interest in politics. Unfortunately, such criticisms, mainly qualitative, have not yet resulted in methodological proposals that are used in standard surveys to better measure young people's political interest. Notwithstanding these measurement issues, political interest has been found to be a good predictor of political participation for both young people and for adults (García-Albacete, 2014) and has provided a reliable measure of future political engagement over time and across countries. Furthermore, there is no reason to expect that it performs worse for some groups among young people than for others.

Our interest lies mainly in the independent variable immigrant status (native, immigrant, and child of immigrant[s]) and national identification, as well as the interaction between these two variables. Immigrant status is measured based on the generated generation variable included in the CILS4EU data (Dollmann, Jacob, \& Kalter, 2014). We transformed this generated variable to include three groups: immigrants are respondents who reported to be foreign-born; children of immigrants are respondents whose parents (at least one) are foreignborn; and finally, the rest of the respondents, including respondents with one or more foreign-born grandparents, were classified as natives (see Table A1 in the Appendix). We also tested an alternative model in which grandchildren of at least two foreign-born grandparents were coded together with children of immigrants. The results (presented in Tables A7 and A8 in the Appendix) show that the main findings are robust. In any case, the number of third-generation immigrants in the sample was very small ranging between $6 \%$ in England and 2\% in the Netherlands.

National identification was measured with the question of how strongly respondents feel English, German, Dutch or Swedish, respectively. Answers ranged from 1 "not at all strongly" to 4 "very strongly." Due to the skewness of this variables' distribution, we grouped the first and second response categories of this variable together. In measuring national identification in this manner, we deviate from previous studies that maintained that political engagement of immigrants depends on their ethnic as well as national identification, and not only the latter (e.g., Martinovic \& Verkuyten, 2014; Simon \& Grabow, 2010; Simon, Reichert, \& Grabow, 2013). We decided to focus on this form of identification because we think it is national and not ethnic identification that may increase respondents' interest in the political sphere of their society and engage in it. Empirically, the CILS4EU data asks respondents whether they identify with the survey country and whether they identify with a different group in two separate items. Although one could construct an inte- grated measure from these items, this measure does not fully capture the notion of dual identity. We thus chose to estimate the effect of ethnic identification which correlates negatively with national identification (Pearson's $r=-0.45$ ) independently. Ethnic identification is measured by items asking respondents whether or not they identify with a group other than their survey country, and if so, to what extent. We combined these two items into one scale ranging from 0 "does not identify with an additional group" to 3 "identify very strongly with another group."

In addition to ethnic identification, we include in our models several control variables. In terms of assimilation related predictors, we first control for perceived discrimination, measured with a variable asking "How often do you feel discriminated against or treated unfairly?" in four different scenarios (see Table A1 in the Appendix). We recoded the sum of the reports across all contexts into two categories: Either respondents never felt discriminated against or they did. We measure friendship patterns by comparing respondents reporting that at least half of their friends are of the respective "other" group to those who reported a smaller share of native friends, or alternatively friends with an immigrant background. Language preferences are measured with a battery asking the respondents what second language they speak in different social contexts (see Table A1), if at all. We used the sum index of the frequency of use across the three contexts. Respondents reporting not to use a second language were coded 0 . Nationality has three categories 0 "only survey country nationality," 1 "only origin country nationality" and 2 "both." In Sweden, none of the respondents reported holding a dual citizenship. To account for the country of origin of the respondents we constructed a regional origin variable in which we grouped countries from substantively meaningful regions together that represent the main regions from which immigrants in England, Germany, the Netherlands and Sweden arrived. All countries have, for example, a large share of "Western" mainly European immigrants. However, while in England Asian immigrants are a relatively large group, in the Netherlands it is the Antilleans. Both Germany and the Netherlands have a large Turkish community (see Table A3 in the Appendix).

In addition to the assimilation-related control variables, we include further variables in the model that were previously shown to be associated with political interest. First, we included a measure for respondents' social activities (participation in associations or clubs) that have a positive effect on political interest and political participation (Verba et al., 1995). Attendance of religious activities serves as an additional proxy for social activities. Second, we control the reported frequency of talking about politics at home as a measure of parental influence that has a large effect on the early development of political interest (for a review see Jennings et al., 2009). Finally, we include respondents' sex because girls have been found to report being less interested in politics than 
boys already at an early age (Greenstein, 1965; van Deth, Abendschön, \& Vollmar 2011).

The CILS4EU project also collected information from the respondents' parents. This information is however not complete. Due to a large number of missing cases, we decided to exclude parental information from our main analysis. Still, we corroborated the robustness of our results by replicating our models including parental education (whether they have an university degree) and mothers' national identification (the results are available in Table A4 in the Appendix).

Before we test the hypotheses listed above, we would like to shortly describe the composition of the sample (the same information is presented in Table $A 2$ in the Appendix only for IIB). The description is based on the weighted sample $(\mathrm{N}=11,747)$ after listwise deletion of the missing cases (percentage missing among the independent variables ranged between $0.5 \%$ and $7 \%$; the depended variable suffered from about $14.5 \%$ missing cases). As indicated in Table 1, in all four countries natives comprise the largest share among the respondents followed by children of immigrants. In England and the Netherlands, immigrants make some $3 \%$ to $9 \%$ of the sample. The share of respondents with a very strong national identification is rather high across all countries and that of ethnic identification much lower. Interest in poli-

Table 1. Descriptive statistics of the sample in the analysis with weights. Source: CILS4EU data.

\begin{tabular}{|c|c|c|c|c|}
\hline & England & Germany & The Netherlands & Sweden \\
\hline $\begin{array}{l}\text { Political interest (original scale) } \\
\% \text { Strong political interest }\end{array}$ & $\begin{array}{l}2.0(1.1) \\
25.1 \%\end{array}$ & $\begin{array}{c}2.8(1.1) \\
65.3 \%\end{array}$ & $\begin{array}{c}2.2(0.99) \\
40.9 \%\end{array}$ & $\begin{array}{c}2.1(1.1) \\
32.3 \%\end{array}$ \\
\hline $\begin{array}{l}\text { Immigrant status: } \\
\text { Native } \\
\text { Immigrant } \\
\text { Child of immigrant(s) }\end{array}$ & $\begin{array}{c}74.9 \% \\
9 \% \\
15.9 \%\end{array}$ & $\begin{array}{c}76 \% \\
4.4 \% \\
19.6 \%\end{array}$ & $\begin{array}{c}85.6 \% \\
3.2 \% \\
11.2 \%\end{array}$ & $\begin{array}{c}72.4 \% \\
7.1 \% \\
20.4 \%\end{array}$ \\
\hline$\%$ Very strong national identification & $52.5 \%$ & $61.4 \%$ & $58.2 \%$ & $64.5 \%$ \\
\hline$\%$ Very strong ethnic identification & $7.5 \%$ & $7.9 \%$ & $5.8 \%$ & $7.3 \%$ \\
\hline Use of second language & $0.7(1.7)$ & $0.9(1.9)$ & $0.8(1.9)$ & $0.9(1.9)$ \\
\hline $\begin{array}{l}\text { Nationality: } \\
\text { Only of survey country } \\
\text { Only of other country } \\
\text { Survey country and other }\end{array}$ & $\begin{array}{c}85.7 \% \\
5.1 \% \\
9.2 \%\end{array}$ & $\begin{array}{c}87.1 \% \\
6.3 \% \\
6.6 \%\end{array}$ & $\begin{array}{c}95.8 \% \\
3.1 \% \\
1.1 \%\end{array}$ & $\begin{array}{c}96.1 \% \\
3.9 \%\end{array}$ \\
\hline $\begin{array}{l}\text { Mixed friendships: } \\
\text { No } \\
\text { Yes }\end{array}$ & $\begin{array}{l}80.7 \% \\
19.3 \%\end{array}$ & $\begin{array}{l}79.5 \% \\
20.5 \%\end{array}$ & $\begin{array}{l}88 \% \\
12 \%\end{array}$ & $\begin{array}{l}77.3 \% \\
22.7 \%\end{array}$ \\
\hline $\begin{array}{l}\text { Discrimination: } \\
\text { No } \\
\text { Yes }\end{array}$ & $\begin{array}{l}39.6 \% \\
60.4 \%\end{array}$ & $\begin{array}{l}33.7 \% \\
66.3 \%\end{array}$ & $\begin{array}{l}72.6 \% \\
27.4 \%\end{array}$ & $\begin{array}{c}56.9 \% \\
43 \%\end{array}$ \\
\hline Talk to parents about politics & $2.8(1.2)$ & $2.9(1.1)$ & $2.9(1.2)$ & $2.7(1.1)$ \\
\hline Associationism & $2.8(1.4)$ & $3.2(1.3)$ & $3.5(1.1)$ & $3.1(1.4)$ \\
\hline $\begin{array}{l}\text { Religious activities: } \\
\text { Less than once a month } \\
\text { At least once a month }\end{array}$ & $\begin{array}{l}81.6 \% \\
18.4 \%\end{array}$ & $\begin{array}{l}80.8 \% \\
19.2 \%\end{array}$ & $\begin{array}{l}90.1 \% \\
9.9 \%\end{array}$ & $\begin{array}{c}90.65 \% \\
9.4 \%\end{array}$ \\
\hline $\begin{array}{l}\text { Gender: } \\
\text { Male } \\
\text { Female }\end{array}$ & $\begin{array}{l}48 \% \\
52 \%\end{array}$ & $\begin{array}{l}49 \% \\
51 \%\end{array}$ & $\begin{array}{l}48.7 \% \\
51.3 \%\end{array}$ & $\begin{array}{l}49.9 \% \\
50.1 \%\end{array}$ \\
\hline $\begin{array}{l}\text { Region of origin: } \\
\text { Africa and Middle East } \\
\text { Asia } \\
\text { Latin America and Caribbean } \\
\text { Europe and North America } \\
\text { Survey country }\end{array}$ & $\begin{array}{c}5.1 \% \\
12.7 \% \\
2.6 \% \\
4.6 \% \\
75 \%\end{array}$ & $\begin{array}{c}7.3 \% \\
2.3 \% \\
1.2 \% \\
13.2 \% \\
76 \%\end{array}$ & $\begin{array}{c}3.5 \% \\
3.9 \% \\
3 \% \\
4 \% \\
85.6 \%\end{array}$ & $\begin{array}{c}7.9 \% \\
4 \% \\
1.9 \% \\
13.7 \% \\
72.4 \%\end{array}$ \\
\hline $\mathrm{N}$ & 2,562 & 2,638 & 3,008 & 3,539 \\
\hline
\end{tabular}


tics is highest in Germany with $65 \%$ of the sample interested in politics and lowest in England with about $25 \%$ of the sample.

To put these findings into context we also looked into several indexes comparing the four countries both in terms of their integration policies and in terms of political engagement. In terms of integration policy, the MIPEX index data from 2012 (Huddleston, Bilgili, Joki, \& Vankova, 2015) indicate that the countries are rather similar to each other. Germany, the Netherlands and England range between 64 (in NL) and 57 (in the UK) points in their integration policy index and Sweden has a higher value of 80 points. This data is in line with Joppke's observation that since the mid-2000s European integration policies are converging (Joppke, 2007). In terms of political engagement, norms are different across countries, for instance, electoral turnout is highest in Sweden followed by the Netherlands, Germany, and England (for the years 2009 and 2010, as well as 2013 to 2015; International IDEA, 2019). As indicated in the European Social Survey data (European Social Survey, 2014) Political interest differs across countries also, with the highest level in Germany, and then Sweden, and the Netherlands. The English show significantly lower levels of political interest (see Figure A1 in the Appendix).

In what follows we present the results of several logistic regression models we estimated in order to test the hypotheses above. Across all models, we pooled the data from the four countries together and included dummy variables to be able to estimate country-effects. We also calculate clustered standard errors because of the clustering of individuals in countries, schools, and classes. We use Sweden, which has a somewhat higher score on the integration policy index, as the reference point.

Model 1 in Table 1 serves to test the main relations between immigrant status and interest in the politics of the receiving society. Model 2 in the same Table also includes national identification to test whether this variable significantly predicts political interest. This is a precondition for the next model presented in Figure 1 where we test our third hypothesis about the moderation of national identification in the relationship tested in model 1. This model was also estimated with the control variables namely friendship and language preferences, ethnic identification, nationality, region of origin, and discrimination perception as well as political socialization at home, associationism and gender as can be seen in Table A5 in the Appendix. Model 3 in Table 1 tests the robustness of the findings from model 1 after adding the same control variables.

\section{Findings}

Table 2 presents the results of the logit estimation models in the form of odds ratios. In model 1, which only includes the variable immigrant status, we see no significant differences in the odds of immigrants and of natives to be politically interested. Thus, our first hypoth- esis that immigrants will show a lower interest in politics compared with natives finds no empirical support at this stage. To that, results imply that immigrants and children of immigrants show higher and not lower odds than natives to be interested in the politics of the survey country. Our second hypothesis, that differences found between immigrants and natives will be larger than those found between children of immigrants and natives was also not corroborated. Specifically, the results indicate that it is the children of immigrants who significantly differ from natives in their political interest and not the immigrants. Model 1 also conveys that English respondents' odds to be politically interested are lower than Swedish respondents' odds, whereas German respondents' odds to be politically interested are nearly 4 times larger than those of respondents in Sweden. Among respondents in the Netherlands, their odds to be politically interested are 1.49 as large as those of respondents in Sweden. In model 2 we included our second variable of interest, namely national identification, which, as expected, positively predicts interest in the politics of the receiving society among the respondents.

Our third hypothesis is the most relevant theoretically. We expect that the odds of IIBs to be politically interested will increase as a function of their national identification $(\mathrm{H} 3)$. Testing this last expectation requires adding an interaction term between national identification and immigrant status to the models presented above (see Table A5 in the Appendix for detailed results). We tested the interaction both in the simplest model (model 2 in Table 2 ) and in the model with all control variables (model 3 in Table 2). Figure 1 shows the results for the simpler model which, as we show in the Appendix (Table A5) did not change much with the inclusion of the control variables. The findings show that in line with our hypothesis, national identification moderates the relation between immigrant status and political interest. Specifically, Figure 1 shows that among IIBs the probability to be interested in the politics of the receiving country increases as national identification becomes stronger. The effect is particularly large for immigrant respondents for which the probability to be interested in politics doubles, increasing from $38 \%$ for those with not a very strong national identification to $62 \%$ for those that identify very strongly (see Figure 1). Among children of immigrants, the larger difference in the probability to be politically interested is found between those who do not identify nationally at all or not very strongly (38\%) and those who identify somewhat strongly (55\%). Corroborating the uncertainty hypothesis, we do not see the same effect among natives who, we contend, are unlikely to suffer from uncertainty in their national group membership.

We also tested these results using a formal (lincom) test (Buis, 2010) which showed that children of immigrants who identified "somewhat strongly" were 1.5 times more likely to be interested in the politics of the receiving society compared to those who did not identify nationally (or identified "not at all strongly"). Among 
Table 2. Odds ratios (robust SE) from the pooled logit model predicting the probabilities to report interest in politics of the survey country (weighted sample, listwise deletion). Source: CILS4EU data; own analysis.

\begin{tabular}{|c|c|c|c|}
\hline & M1 & M2 & M3 \\
\hline \multirow[t]{2}{*}{ Immigrant } & 1.11 & 1.25 & 0.79 \\
\hline & $(0.16)$ & $(0.18)$ & $(0.20)$ \\
\hline \multirow[t]{2}{*}{ Child of immigrant(s) } & $1.21 * *$ & $1.29 * * *$ & 0.73 \\
\hline & $(0.11)$ & $(0.12)$ & $(0.14)$ \\
\hline \multirow[t]{2}{*}{ National identification (somewhat strongly, ref: not at all/not very) } & & $1.40 * *$ & 1.25 \\
\hline & & $(0.19)$ & $(0.18)$ \\
\hline \multirow[t]{2}{*}{ National identification (very strongly) } & & $1.47 * * *$ & $1.33^{* *}$ \\
\hline & & $(0.19)$ & $(0.19)$ \\
\hline \multirow[t]{2}{*}{ England } & $0.71 * * *$ & $0.71 * * *$ & $0.58 * * *$ \\
\hline & $(0.05)$ & $(0.06)$ & $(0.06)$ \\
\hline \multirow[t]{2}{*}{ Germany } & $3.97 * * *$ & $4.04^{* * *}$ & $4.40 * * *$ \\
\hline & $(0.31)$ & $(0.31)$ & $(0.40)$ \\
\hline \multirow[t]{2}{*}{ The Netherlands } & $1.49 * * *$ & $1.49 * * *$ & $1.38 * * *$ \\
\hline & $(0.14)$ & $(0.14)$ & $(0.15)$ \\
\hline \multirow[t]{2}{*}{ No ethnic identification (ref: identify very strongly) } & & & 1.02 \\
\hline & & & $(0.18)$ \\
\hline \multirow[t]{2}{*}{ Ethnic identification: not at all/not very strongly } & & & 1.25 \\
\hline & & & $(0.27)$ \\
\hline \multirow[t]{2}{*}{ Ethnic identification somewhat strongly } & & & 1.17 \\
\hline & & & $(0.21)$ \\
\hline \multirow[t]{2}{*}{ Girl } & & & $0.55^{* * *}$ \\
\hline & & & $(0.05)$ \\
\hline \multirow[t]{2}{*}{ Citizenship $=$ survey country and other } & & & 0.79 \\
\hline & & & $(0.15)$ \\
\hline \multirow[t]{2}{*}{ Citizenship = only other country } & & & 0.80 \\
\hline & & & $(0.15)$ \\
\hline \multirow[t]{2}{*}{ Political discussion at home } & & & $2.28 * * *$ \\
\hline & & & $(0.09)$ \\
\hline \multirow[t]{2}{*}{ Mixed friendships } & & & $1.43^{* *}$ \\
\hline & & & $(0.21)$ \\
\hline \multirow[t]{2}{*}{ Use of second language } & & & 1.00 \\
\hline & & & $(0.03)$ \\
\hline \multirow[t]{2}{*}{ Associationism } & & & $1.08 * *$ \\
\hline & & & $(0.03)$ \\
\hline \multirow[t]{2}{*}{ Religious activities } & & & $1.22 * * *$ \\
\hline & & & $(0.05)$ \\
\hline \multirow[t]{2}{*}{ Felt discriminated rarely or more often } & & & 1.00 \\
\hline & & & $(0.01)$ \\
\hline \multirow[t]{2}{*}{ Africa and the Middle East } & & & $1.81 * * *$ \\
\hline & & & $(0.33)$ \\
\hline \multirow[t]{2}{*}{ Asia } & & & $1.75^{* * *}$ \\
\hline & & & $(0.34)$ \\
\hline \multirow[t]{2}{*}{ Latin America and the Caribbean } & & & 1.27 \\
\hline & & & $(0.36)$ \\
\hline Constant & $0.45 * * *$ & $0.32 * * *$ & $0.02 * * *$ \\
\hline & $(0.02)$ & $(0.04)$ & $(0.01)$ \\
\hline Observations & 11,747 & 11,747 & 11,747 \\
\hline AIC & 1150879 & 1148772 & 962484.7 \\
\hline Log pseudolikelihood & -575433.36 & -574377.87 & -481219.35 \\
\hline
\end{tabular}

Notes: Robust se (eform) in parentheses; ${ }^{* *} p<0.01,{ }^{* *} p<0.05,{ }^{*} p<0.10$. 


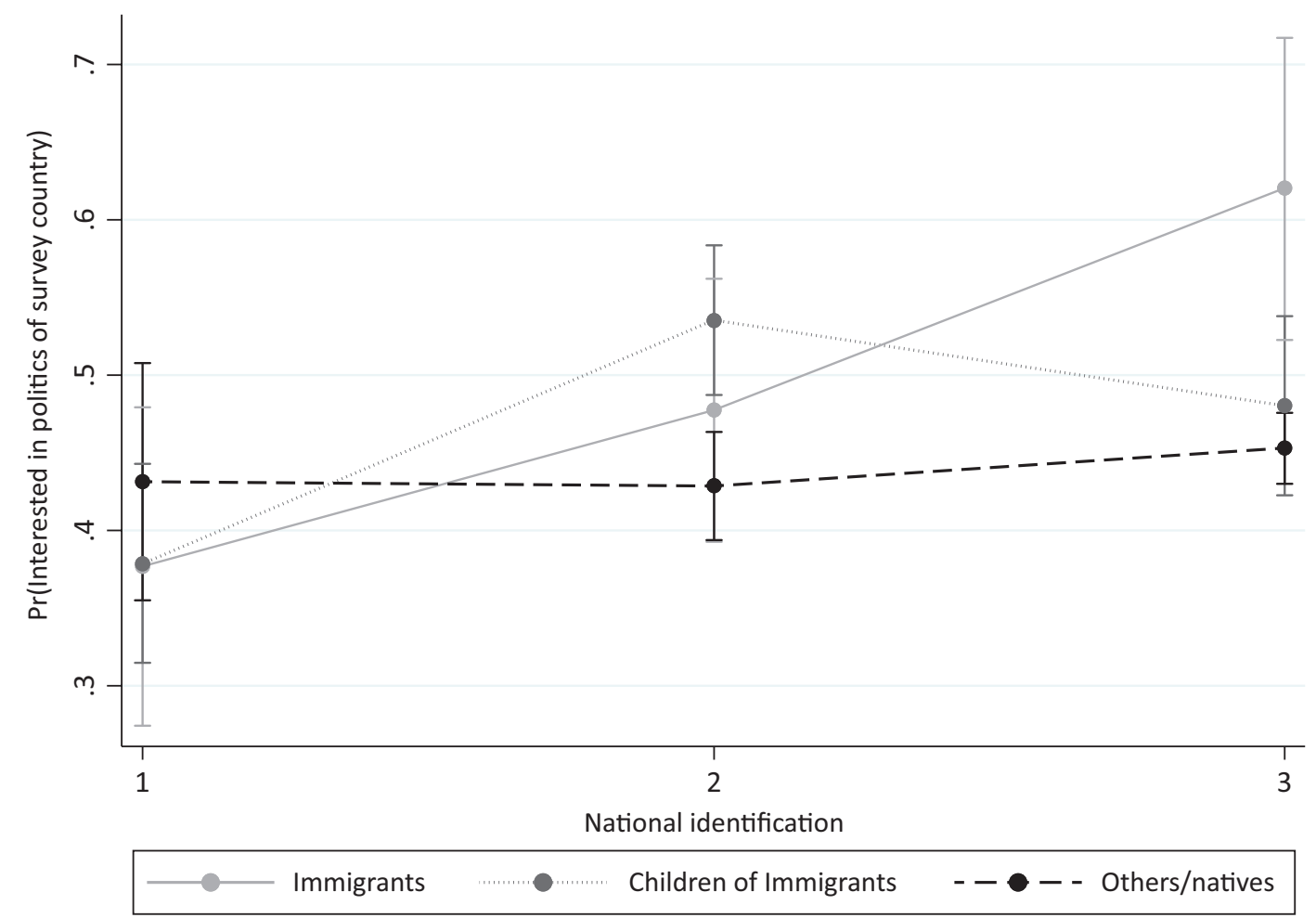

Figure 1. Predicted probabilities of being interested in the politics of the survey country according to strength of national identification and immigrant status. Note: Estimates based on model 1 in Table A5 in the Appendix. Source: CILS4EU data; own analysis.

immigrants, the difference was at 0.87 . To the contrary, immigrants who identified "very strongly" with their respective survey country were 2.14 times more likely to be interested in its politics compared to immigrants with low or no national identification at all, whereas this difference was at 1.31 for children of immigrants. Due to the relatively similar integration policies in the four countries under scrutiny, we have not developed hypotheses regarding possible country differences in the interaction between national identification and immigrant status. Results from country-specific estimations of the interaction effect (see Figure $A 2$ in the Appendix) indicate however that the moderation effect of national identification on the probabilities of IIBs and natives to be politically interested differs across the countries, in particular among children of immigrants, and natives. The one common trend is that among immigrants the probability to be politically interested increases with levels of national identification.

Before we move on the conclusions section, we would like to point out a few additional results from model 3 in Table 2 (and model 2 in Table A5 in the Appendix). We will not describe all results in detail here, but a few of the findings do deserve our attention. The first noteworthy finding in model 3 is the change in the direction of the immigrant status coefficients which are, however, not statistically significant at the 0.10 level (they are, in model 2 in Table A5). Regarding our second main variable of interest, national identification, the results confirm again that a stronger national identification implies higher levels of political interest. The country differences observed in models 1 and 2 hold also in model 3.

In line with previous research, model 3 shows that respondents whose parents discuss politics at home have twice the odds to be politically interested than respondents whose parents do not talk about politics at home. We also see that boys have twice the odds that girls do to be politically interested. Associationism and religious activities also increase the odds of being interested in the politics of the survey country. Similarly, respondents with mixed friendships have higher odds to be politically interested than respondents with homogeneous friendship ties. We understand this result in line with the positive effect of heterogeneous networks (Granovetter, 1973). Other assimilation-related predictors were less relevant for the respondents' interest in the receiving society's politics. Finally, model 3 conveys that among respondents from African, Middle Eastern, and Asian origin, the odds to be interested in the politics of the receivingcountry are higher than among natives and individuals with a European origin. Table A6 in the Appendix show the same models for IIB only, where one can also see that differences in political interest between immigrants and children of immigrants are not statistically significant.

\section{Conclusions and Outlook}

As diversity in European societies rises, understanding whether and how new immigrant groups and their descendants assimilate becomes increasingly relevant. 
Within this context, we focus our attention on the issue of political interest, a key determinant of political assimilation, which until now remained understudied. We investigate political interest among youth in four European immigrant-receiving countries. Our focus on youth allows us to learn about the emergence of political interest, which according to the literature develops in adolescence. In particular, we look into the relations between political interest and national identification, another personality element that develops during this stage in the life-course, among individuals with and without an immigrant background. We first investigated whether interest in the politics of the receiving society differs between natives, children of immigrants and immigrants. Second, we tested whether such differences can be explained by differential levels of national identification. The assumption here was that due to their identity uncertainty, IIBs will show higher political interest as their national identification becomes stronger.

As mentioned elsewhere in the article, we did not attempt to solve the causal debate regarding the relations between national identification and political interest. Instead, we used data from the second wave of the CILS4EU to investigate the relations between assimilation and interest in the politics of the survey country, assuming that national identification is an important predictor of it. Interest in the politics of the receiving country was only measured twice in the CILS4EU project crossnationally, limiting our possibilities to measure its longterm relationship with national identification. An obvious extension of this project is thus to use the longitudinal version of the CILS4EU in Germany, where the question was included in further waves. Furthermore, a question could be raised as to the potential of class or schoollevel information that is available in the CILS4EU data, of which we made no use. Regarding the sample, it is important to note that the data covers a highly selective set of countries in Europe which warns caution regarding generalizing the conclusions to other countries. Future research should thus try to include more countries and consider macro-level mechanisms to account for differences between them.

Notwithstanding its limitations, the current study is a first and necessary step that provides important insights into immigrants' political assimilation. The findings presented above indicate first that national identification, defined as a sense of attachment to the in-group, is an important mechanism that positively contributes to political interest among youth in Europe. Given that democracies require, by definition, citizens' political participation, and that political interest is a prerequisite of such participation, our findings indicate that European democracies would be smart in exploring potential ways to increase national identification among young persons. After all, whether they develop political interest-or not-at an early age will determine their future participatory behavior and among others their electoral turn-out.
Second, our findings show that the relevance of national identification for political interest differs between natives and IIBs. Two issues arise from this result: first, considering the importance of developing national identification among young people, this finding speaks for the fact that nations compete with a long list of other social groups with which youth, and particularly native youth identifies. Thus, the task of increasing this identification among them should not be underestimated. Second, considering the stronger association between national identification and political interest among immigrants, we believe this finding supports previous indications for the assimilation of immigrants in European societies. Moreover, it shows how the attachment of immigrants to the receiving society increases their chances to be interested in its politics. This finding thus indicates that national identification of immigrants holds an important key for sustaining democracy in more than one way. By increasing national identification among immigrants, and to some extent also children of immigrants, receiving societies in Europe may foster their political participation and increase democratization in their highly diversified societies. Moreover, by providing immigrants the opportunity to raise their voice in politics, democracies can become more equalitarian. Hochman (2011) finds in this context that party identification increases the odds of IIBs in Germany to report intentions of naturalization.

Finally, the country-differences we observe in our data remain to be explained. Although this is a goal that goes beyond the scope of this article, our first interpretation refers to the important role of the prestige of political interest as a norm of citizenship in each country on the one hand, and the openness of the political system to immigrants in terms of assimilation on the other. While national identification matters little for the political interest of young people in Sweden, it matters significantly in Germany. In addition, in Germany political interest is relatively high. The combination of both factors could explain why in Germany those immigrants or children of immigrants that are politically interested are the ones motivated due to their positive identification with the country and their willingness to assimilate. This is a speculation that requires further analysis and provides a future venue for research.

\section{Acknowledgments}

We thank the three anonymous reviewers as well as members of the GESIS Political Science Roundtable (2018) for their useful and constructive comments. This work was supported by the Spanish Ministry of Economy and Competitiveness, grant CSO2016-75090-R, and by the GESIS-Leibniz Institute for the Social Sciences.

\section{Conflict of Interests}

The authors declare no conflict of interests. 


\section{References}

Alba, R., \& Nee, V. (1997). Rethinking assimilation theory for a new era of immigration. The International Migration Review, 31(4), 826-874.

Bass, L. E., \& Casper, L. M. (2001). Impacting the political landscape: Who registers and votes among naturalized Americans? Political Behavior, 23(2), 103-130.

Bevelander, P., \& Pendakur, R. (2011). Voting and social inclusion in Sweden. International Migration, 49(4), 67-92.

Buis, M. L. (2010). Stata tip 87: Interpretation of interactions in nonlinear models. Stata Journal, 10(2), 305-308.

Diehl, C., \& Schnell, R. (2006). "Reactive ethnicity" or "Assimilation"? Statements, arguments, and first empirical evidence for labor migrants in Germany. International Migration Review, 40(4), 786-816.

Dollmann, J., Jacob, K., \& Kalter, F. (2014). Examining the diversity of youth in Europe. A classification of generations and ethnic origins using CILS4EU data (Technical Report). Mannheim: Mannheimer Zentrum für Europäische Sozialforschung.

European Social Survey. (2014). ESS7-2014 Data. File edition 2.2. European Social Survey. https://doi.org/ 10.21338/NSD-ESS7-2014

Erikson, E. (1968). Identity: Youth and crisis. New York, NY: Norton \& Company.

Fernandes-Jesus, M., Malafaia, C., Ribeiro, N., \& Menezes, I. (2015). Participation among youth, women and migrants: Findings from Portugal. In M. Barret \& B. Zani (Eds.), Political and civic engagement: Multidisciplinary perspectives (pp. 311-333). Surrey: Routledge.

Ferrín, M., Fraile, M., García-Albacete, G. M. \& Gómez, R. (2019). The gender gap in political interest revisited. International Political Science Review. Advanced online publication. https://doi.org/10.1177/ 0192512119860260

Gans, H. J. (1979). Symbolic ethnicity: The future of ethnic groups and cultures in America. Ethnic and racial studies, 2(1), 1-20.

Gans, H. J. (1992). Second-generation decline: Scenarios for the economic and ethnic futures of the post-1965 American immigrants. Ethnic and Racial Studies, 15(2), 173-192.

García-Albacete, G. M. (2013). Promoting political interest in schools: The role of civic education. In S. Abendschön (Ed.), Growing into politics: Contexts and timing of political socialisation (pp. 91-113). Oxon: ECPR Press.

García-Albacete, G. M. (2014). Young people's political participation in Western Europe: Continuity or generational change. Basingstoke: Palgrave Macmillan.

Granovetter, M. S. (1973). The strength of weak ties. The American Journal of Sociology, 78(6), 1360-1380.

Greco Morasso, S. (2012). Learning as a precondition of immigrants' interest and engagement. Human Af- fairs, 22(3), 313-324.

Greenstein, F. I. (1965). Children and politics. New Haven, CT: Yale University Press.

Hindriks, P., Verkuyten, M., \& Coenders, M. (2017). Evaluating political acculturation strategies: The perspective of the majority and other minority groups. Political Psychology, 38(5), 744-756.

Hochman, O. (2010). Ethnic identification preferences among Germany's immigrants and their descendants: A comprehensive perspective (Unpublished Doctoral dissertation). University of Mannheim, Mannheim, Germany.

Hochman, O. (2011). Determinants of positive naturalisation intentions among Germany's labour migrants. Journal of Ethnic and Migration Studies, 37(9), 1403-1421.

Hogg, M. A., Adelman, J. R., \& Blagg, R. D. (2010). Religion in the face of uncertainty: An uncertainty-identity theory account of religiousness. Personality and Social Psychology Review, 14(1), 72-83.

Hogg, M. A., Hardie, E. A., \& Reynolds, K. J. (1995). Prototypical similarity, self-categorization, and depersonalized attraction: A perspective on group cohesiveness. European Journal of Social Psychology, 25(2), 159-177.

Hogg, M. A., \& Reid, S. A. (2006). Social identity, selfcategorization, and the communication of group norms. Communication Theory, 16(1), 7-30.

Huddleston, T., Bilgili, Ö., Joki, A. L., \& Vankova, Z. (2015). Integration policies: Who benefits? The development and use of indicators in integration debates. Migrant Integration Policy Index 2015. Retrieved from http:// mipex.eu

Huddy, L. (2001). From social to political identity: A critical examination of social identity theory. Political Psychology, 22(1), 127-156.

International IDEA. (2019). Voter turnout dataset. International IDEA. Retrieved from https://www.idea.int/ data-tools/data/voter-turnout

Jennings, M. K., Stoker, L., \& Bowers, J. (2009). Politics across generations: Family transmission reexamined. The Journal of Politics, 71(3), 782-799.

Joppke, C. (2007). Transformation of immigrant integration: Civic integration and antidiscrimination in the Netherlands, France, and Germany. World Politics, 59(2), 243-273.

Kalter, F., Heath, A. F., Hewstone, M., Jonsson, J. O., Kalmijn, M., Kogan, I., \& van Tubergen, F. (2017). Children of immigrants longitudinal survey in four European countries (CILS4EU): Data file version 3.3.0. https://doi.org/10.4232/cils4eu.5656.3.3.0

Kalter, F. (2018). Setting "Spanish legacies" into further context: Some findings and thoughts from CILS4EU. Ethnic and Racial Studies, 41(3), 500-508.

Kim, Y., \& Amnâ, E. (2015). Civic engagement among immigrant youth in Sweden: Do parental norms or immigration generation matter? In M. Barrett \& B. Zani (Eds.), Political and civic engagement 
multidisciplinary perspectives (pp. 248-267). Surrey: Routledge.

Kinder, D. R., \& Sears, D. O. (1985). Public opinion and political action. In G. Lindzey \& E. Aronson (Eds.), The handbook of social psychology (3rd ed., pp. 659-741). New York, NY: Random House.

Klandermans, P. G. (2014). Identity politics and politicized identities: Identity processes and the dynamics of protest. Political Psychology, 35(1), 1-22.

Klandermans, P. G., van der Toorn, J., \& van Stekelenburg, J. (2008). Embeddedness and identity: How immigrants turn grievances into action. American Sociological Review, 73(6), 992-1012.

Liberson, S. (1973). Generational differences among blacks in the north. American Journal of Sociology, 79(3), 550-565.

Lien, P. (2004). Asian Americans and voting participation: Comparing racial and ethnic differences in recent U.S. elections. International Migration Review, 38(2), 493-517.

Martinovic, B., \& Verkuyten, M. (2014). The political downside of dual identity: Group identifications and religious political mobilization of Muslim minorities. British Journal of Social Psychology, 53(4), 711-730.

Messina, A. M. (2006). The political incorporation of immigrants in Europe: Trends and implications. In A. M. Messina \& G. Lahav (Eds.), The migration reader: Exploring politics and policies (pp. 470-93). Boulder: Lynne Rienner Publishers.

Milbrath, L. W. (1965). Political participation: How and why do people get involved in politics? Skokie: Rand McNally \& Co.

Monforte, P., \& Morales, L. (2018). The participation, mobilization and political representation of migrants in Europe. In A. Weinar, S. Bonjour, \& L. Zhyznomirska (Eds.), The Routledge handbook of the politics of migration in Europe (pp. 126-136). London: Routledge.

Neundorf, A., Niemi, R. G., \& Smets, K. (2016). The compensation effect of civic education on political engagement: How civics classes make up for missing parental socialization. Political Behavior, 38(4), 921-949.

Neundorf, A., Smets, K., \& García-Albacete, G. M. (2013). Homemade citizens: The development of political interest during adolescence and young adulthood. Acta Politica, 48(1), 92-116.

O'Toole, T., Lister, M., Marsh, D., Jones, S., \& McDonagh, A. (2003). Tuning out or left out? Participation and non-participation among young people. Contemporary Politics, 9(1), 45-61.

Phinney, J. S. (1990). Ethnic identity in adolescents and adults: Review of research. Psychological Bulletin, 108(3), 499-514.

Portes, A., \& Rumbaut, R. G. (2001). Legacies: The story of the immigrant second generation. Berkeley, CA: University of California Press.

Prior, M. (2010). You've either got it or you don't? The stability of political interest over the life cycle. The
Journal of Politics, 72(3), 747-766.

Quintelier, E. (2015). Engaging adolescents in politics: The longitudinal effect of political socialization agents. Youth \& Society, 47(1), 51-69.

Ramakrishnan, S. K., \& Espenshade, T. (2001). Immigrant incorporation and political participation in the United States. International Migration Review, 35(3), 870-909.

Schwartz, S. J., Coté, J. E., \& Jensen Arnett, J. (2005). Identity and agency in emerging adulthood: Two developmental routes in the individualization process. Youth Society, 37(6), 201-229.

Simon, B., \& Grabow, O. (2010). The politicization of migrants: Further evidence that politicized collective identity is a dual identity. Political Psychology, 31(5), 717-738.

Simon, B., \& Klandermans, B. (2001). Politicized collective identity: A social psychological analysis. American Psychologist, 56(4), 319-331.

Simon, B., Loewy, M., Stürmer, S., Weber, U., Freytag, P., Habig, C., . . \& \& Spahlinger, P. (1998). Collective identification and social movement participation. Journal of Personality and Social Psychology, 74(3), 646-658.

Simon, B., Reichert, F., \& Grabow, O. (2013). When dual identity becomes a liability: Identity and political radicalism among migrants. Psychological Science, 24(3), 251-257.

Tajfel, H. (1974). Intergroup behavior, social comparison and social change. Unpublished Katz-Newcomb Lectures. Ann Arbor, MI: University of Michigan.

Terriquez, V., \& Kwon, H. (2015). Intergenerational family relations, civic organisations, and the political socialisation of second-generation immigrant youth. Journal of Ethnic and Migration Studies, 41(3), 425-447.

Turner, J. C. (1999). Some current issues in research on social identity and self-categorization theories. Social Identity: Context, Commitment, Content, 3(1), 6-34.

van Deth, J. W. (1990). Interest in politics. In M. K. Jennings, J. W. van Deth, S. H. Barnes, D. Fuchs, F. Heunks, R. Inglehart, ... J. J. A. Thomassen (Eds.), Continuities in political action: A longitudinal study of political orientations in three Western democracies (pp. 275-312). Berlin: De Gruyter.

van Deth, J. W. (2009). The 'good European citizen': Congruence and consequences of different points of view. European Political Science, 8(2), 175-189.

van Deth, J. W., Abendschön, S., \& Vollmar, M. (2011). Children and politics: An empirical reassessment of early political socialization. Political Psychology, 32(1), 147-174.

van Deth, J. W., \& Elff, M. (2004). Politicisation, economic development and political interest in Europe. European Journal of Political Research, 43(3), 477-508.

Verba, S., Schlozman, K. L., \& Brady, H. E. (1995). Voice and equality: Civic voluntarism in American politics. Cambridge, MA: Harvard University Press.

White, S., Nevitte, N., Blais, J., Fournier, P., \& Gidengil, E. (2006). Making up for lost time, Immigrant voter 
turnout in Canada. Electoral Insight, Electoral Participation of Ethnocultural Communities, 8(2), 10-16.

Zhou, M. (1997). Segmented assimilation: Issues, con- troversies and recent research on the new second generation. International Migration Review, 31(4), 975-1008.

\section{About the Authors}

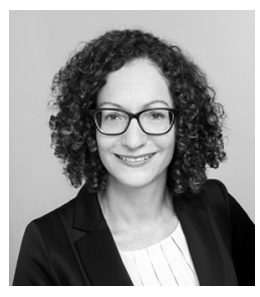

Oshrat Hochman is a Team Leader at GESIS-Leibniz Institute for the Social Sciences in Mannheim, Germany. Her research relates to social integration of immigrants and attitudes towards immigrants and immigration in Europe and Israel, as well as to social inequality primarily in wealth. Her work has been published in journals like the European Social Survey, the International Journal of Comparative Sociology, International Migration, the Journal of Ethnic and Migration Studies, and Research in Social Stratification and Mobility among others.

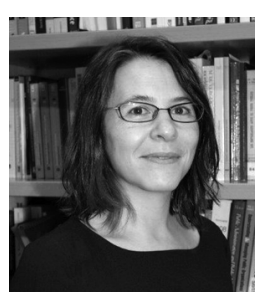

Gema García-Albacete is Assistant Professor at the Department of Social Sciences of Universidad Carlos III de Madrid. Her research relates to citizens' inequalities in political interest, knowledge and political participation across Western democracies. Her work has been published in journals such as West European Politics, International Journal of Press/Politics, Politics \& Gender, the International Journal of Public Opinion Research, or Information, Communication and Society, among others. Her monograph Young People's Political Participation in Western Europe summarizes some of her work on youth and politics. 


\section{Appendix}

Table A1. List of variables and how they were measured.

\begin{tabular}{|c|c|c|}
\hline Variable & Original item & Final measure \\
\hline $\begin{array}{l}\text { Political } \\
\text { interest }\end{array}$ & $\begin{array}{l}\text { How interested are you in survey country's politics? } \\
\text { (1) very much (5) very little or not at all }\end{array}$ & (0) Not interested (1) Interested \\
\hline $\begin{array}{l}\text { Immigrant } \\
\text { status }\end{array}$ & Generated CILS4EU variable & $\begin{array}{l}\text { (1) Immigrants ( } 2 \text { ) Children of immigrants } \\
\text { (0) Other and native }\end{array}$ \\
\hline $\begin{array}{l}\text { National } \\
\text { identification }\end{array}$ & $\begin{array}{l}\text { How strongly do you feel [survey country member] } \\
\text { (1) very strongly to (5) not at all strongly }\end{array}$ & $\begin{array}{l}\text { (1) not at all, not strongly (2) Fairly } \\
\text { strongly (3) very strongly }\end{array}$ \\
\hline $\begin{array}{l}\text { Ethnic } \\
\text { identification }\end{array}$ & $\begin{array}{l}\text { How strongly do you feel you belong to [group 1] (1) very } \\
\text { strongly to (5) not at all strongly }\end{array}$ & $\begin{array}{l}\text { (1) not at all, not strongly (2) Fairly } \\
\text { strongly (3) very strongly }\end{array}$ \\
\hline $\begin{array}{l}\text { Friendship } \\
\text { patterns }\end{array}$ & $\begin{array}{l}\text { Thinking now about all of your friends. How many of them } \\
\text { have a [survey country] background }\end{array}$ & $\begin{array}{l}\text { (0) half or more of friends same group } \\
\text { (1) half or more of friends other group }\end{array}$ \\
\hline $\begin{array}{l}\text { Language } \\
\text { preferences }\end{array}$ & $\begin{array}{l}\text { Is there a language other than <survey country language> } \\
\text { spoken at your home? In this language, how often do you: } \\
\text { Talk to your family, watch TV, talk to your friends }\end{array}$ & $\begin{array}{l}\text { Sum scale among those who reported } \\
\text { "yes" to other language spoken at home }\end{array}$ \\
\hline $\begin{array}{l}\text { Subjective } \\
\text { discrimination } \\
\text { (Round 1) }\end{array}$ & $\begin{array}{l}\text { How often feel discriminated against or treated unfairly/ } \\
\text { In the last } 12 \text { month felt discriminated in: school; } \\
\text { trains/buses/trams/subways; shops/stores/cafés/ } \\
\text { restaurants/ nightclubs; by police or security guards } \\
\text { (1) always to (4) never }\end{array}$ & $\begin{array}{l}\text { (0) never felt discriminated (1) Felt } \\
\text { discriminated rarely or more often }\end{array}$ \\
\hline $\begin{array}{l}\text { Nationality } \\
\text { (Round 1) }\end{array}$ & $\begin{array}{l}\text { What is your nationality (which country is your passport } \\
\text { from)? If you have more than one nationality, please tick } \\
\text { all that apply (1) Only survey country, (2) survey country } \\
\text { and other, (3) only other }\end{array}$ & Same as original item \\
\hline $\begin{array}{l}\text { Political } \\
\text { discussions at } \\
\text { home }\end{array}$ & $\begin{array}{l}\text { In general, how often does/do one or both of your parents } \\
\text { do the following things with you? talk to you about } \\
\text { political and social issues (1) every day to (5) never }\end{array}$ & Same as original item \\
\hline Associationism & $\begin{array}{l}\text { In your spare time how often spend time in a } \\
\text { sports/music/drama/other club (1) every day to (5) never }\end{array}$ & Same as original item \\
\hline $\begin{array}{l}\text { Religious } \\
\text { participation }\end{array}$ & $\begin{array}{l}\text { How often do you visit a religious meeting place (e.g., a } \\
\text { church, mosque, synagogue or temple)? (1) never to } \\
\text { (5) every day }\end{array}$ & Same as original item \\
\hline Girl & Are you a boy or a girl (1) and (2) respectively & (0) boy (1) girl \\
\hline $\begin{array}{l}\text { Region of } \\
\text { origin }\end{array}$ & Generated SILC4EU variable & $\begin{array}{l}\text { Africa and Middle-East; Asia; South } \\
\text { America and the Carribean; Europe } \\
\text { North-America and Oceania; Survey } \\
\text { country }\end{array}$ \\
\hline
\end{tabular}


Table A2. Descriptive statistics of the sample in the analysis with weights (immigrants and children of immigrants only).

\begin{tabular}{|c|c|c|c|c|}
\hline & England & Germany & The Netherlands & Sweden \\
\hline Political interest (original scale) & $2.1(1.1)$ & $2.7(1.2)$ & $2.6(1.0)$ & $2.2(1.1)$ \\
\hline \% Strong political interest & $29.7 \%$ & $60.6 \%$ & $62.3 \%$ & $40.2 \%$ \\
\hline \multicolumn{5}{|l|}{ Immigrant status: } \\
\hline Immigrant & $36.2 \%$ & $18.3 \%$ & $22.3 \%$ & $25.8 \%$ \\
\hline Child of immigrant & $63.8 \%$ & $81.7 \%$ & $77.7 \%$ & $74.2 \%$ \\
\hline$\%$ Very strong National identification & $28 \%$ & $31.9 \%$ & $21.9 \%$ & $26.8 \%$ \\
\hline$\%$ Very strong Ethnic identification & $23.6 \%$ & $26.9 \%$ & $26.6 \%$ & $22.7 \%$ \\
\hline Use of second language & $2.4(2.6)$ & $3.4(2.6)$ & $2.6(2.7)$ & $3.0(2.6)$ \\
\hline \multicolumn{5}{|l|}{ Nationality: } \\
\hline Only of survey country & $47.7 \%$ & $49.8 \%$ & $73.4 \%$ & $85.8 \%$ \\
\hline Only of other country & $17.2 \%$ & $22.9 \%$ & $19.3 \%$ & $14.2 \%$ \\
\hline Survey country and other & $35.1 \%$ & $27.3 \%$ & $7.3 \%$ & - \\
\hline \multicolumn{5}{|l|}{ Mixed friendships: } \\
\hline No & $29.9 \%$ & $23 \%$ & $20.5 \%$ & $24 \%$ \\
\hline Yes & $70.1 \%$ & $77 \%$ & $79.5 \%$ & $76 \%$ \\
\hline$\%$ experienced discrimination & $61.1 \%$ & $61.5 \%$ & $36.2 \%$ & $44.6 \%$ \\
\hline Talk to parents about politics & $2.9(1.2)$ & $2.8(1.2)$ & $3.0(1.2)$ & $2.8(1.2)$ \\
\hline Associationism & $2.8(1.3)$ & $3.0(1.4)$ & $3.1(1.4)$ & $2.9(1.4)$ \\
\hline \multicolumn{5}{|l|}{ Religious participation: } \\
\hline Less than once a month & $63.3 \%$ & $71.6 \%$ & $77.5 \%$ & $85.3 \%$ \\
\hline At least once a month & $36.7 \%$ & $28.4 \%$ & $22.5 \%$ & $14.7 \%$ \\
\hline \multicolumn{5}{|l|}{ Gender: } \\
\hline Boy & $47.7 \%$ & $44.9 \%$ & $44.7 \%$ & $50.6 \%$ \\
\hline Girl & $52.3 \%$ & $55.1 \%$ & $55.3 \%$ & $49.4 \%$ \\
\hline \multicolumn{5}{|l|}{ Country of origin: } \\
\hline Africa and the Middle East & $20.38 \%$ & $30.6 \%$ & $24.4 \%$ & $28.6 \%$ \\
\hline Asia & $50.8 \%$ & $9.5 \%$ & $27.4 \%$ & $14.6 \%$ \\
\hline South America and the Caribbean & $10.5 \%$ & $5 \%$ & $20.5 \%$ & $7 \%$ \\
\hline Europe and north America & $18.3 \%$ & $54.8 \%$ & $27.7 \%$ & $49.7 \%$ \\
\hline $\mathrm{N}$ & 993 & 1113 & 850 & 1481 \\
\hline
\end{tabular}

Source: CILS4EU 
Table A3. Code for country of origin.

\begin{tabular}{|c|c|c|c|c|}
\hline & England & Germany & Netherlands & Sweden \\
\hline \multirow[t]{3}{*}{$\begin{array}{l}\text { Africa and Middle } \\
\text { East (+Turkey) }\end{array}$} & Nigeria, West Africa, & $\begin{array}{l}\text { North Africa, } \\
\text { Lebanon }\end{array}$ & Morocco & $\begin{array}{c}\text { North Africa, } \\
\text { Lebanon, Iraq, Syria, } \\
\text { Iran }\end{array}$ \\
\hline & East Africa & Other Africa & Africa & \\
\hline & Other Africa & & & $\begin{array}{c}\text { East Africa, Somalia } \\
\text { Other Africa }\end{array}$ \\
\hline \multirow[t]{3}{*}{ Asia } & South Asia, East Asia & South Asia, & South Asia, Indonesia & $\begin{array}{l}\text { South Asia, } \\
\text { Southeast Asia }\end{array}$ \\
\hline & $\begin{array}{l}\text { Pakistan, India, } \\
\text { Bangladesh }\end{array}$ & West Asia & West Asia & West Asia \\
\hline & other Asia & other Asia & other Asia & other Asia \\
\hline $\begin{array}{l}\text { Latin America and } \\
\text { the Caribbean }\end{array}$ & $\begin{array}{l}\text { Latin America and the } \\
\text { Caribbean, Caribbean }\end{array}$ & $\begin{array}{l}\text { Latin America } \\
\text { and the } \\
\text { Caribbean }\end{array}$ & $\begin{array}{c}\text { Latin America and the } \\
\text { Caribbean, Surinam, } \\
\text { Antilleans }\end{array}$ & $\begin{array}{l}\text { Latin America and } \\
\text { the Caribbean }\end{array}$ \\
\hline \multirow{5}{*}{$\begin{array}{l}\text { Europe, North } \\
\text { America and } \\
\text { Oceania }\end{array}$} & $\begin{array}{c}\text { North America and } \\
\text { Oceania }\end{array}$ & $\begin{array}{l}\text { North America } \\
\text { and Oceania }\end{array}$ & North America and Oceania & $\begin{array}{c}\text { North America and } \\
\text { Oceania }\end{array}$ \\
\hline & East Europe & \multicolumn{2}{|c|}{ East Europe, FSU, Poland, Former Yugoslavia } & East Europe \\
\hline & \multirow[t]{2}{*}{$\begin{array}{l}\text { South Europe } \\
\text { Italy, Greece }\end{array}$} & South Europe, & South Europe & $\begin{array}{l}\text { Yugoslavia, Poland } \\
\text { South Europe }\end{array}$ \\
\hline & & & & $\begin{array}{c}\text { Finland, Denmark, } \\
\text { Norway }\end{array}$ \\
\hline & Other Europe, Ireland & & Other Europe, West Europe & \\
\hline Missing & Unknown & Unknown & Unknown & Unknown \\
\hline Survey country & Survey country & Survey country & Survey country & Survey country \\
\hline
\end{tabular}


Table A4. Odds ratios (robust SE) from the pooled logit model predicting the probabilities to report interest in politics of the survey country with parental information (weighted sample, listwise deletion). Source: CILS4EU data; own analysis.

\begin{tabular}{|c|c|c|c|}
\hline & M1 & M2 & M3 \\
\hline \multirow[t]{2}{*}{ Immigrant } & $0.33 * *$ & $0.36 * *$ & $0.35 * *$ \\
\hline & $(0.15)$ & $(0.16)$ & $(0.16)$ \\
\hline \multirow[t]{2}{*}{ Child of immigrant(s) } & $0.38 * *$ & $0.39 * *$ & $0.40 * *$ \\
\hline & $(0.15)$ & $(0.15)$ & $(0.16)$ \\
\hline \multirow[t]{2}{*}{ National identification (somewhat strongly, ref: not at all/not very) } & 0.98 & 0.98 & 0.96 \\
\hline & $(0.26)$ & $(0.25)$ & $(0.25)$ \\
\hline \multirow[t]{2}{*}{ National identification (strongly) } & 1.15 & 1.12 & 1.12 \\
\hline & $(0.29)$ & $(0.27)$ & $(0.28)$ \\
\hline \multirow[t]{2}{*}{ Immigrant * national identification somewhat strongly } & $2.24^{*}$ & 2.12 & $2.21 *$ \\
\hline & $(1.07)$ & $(0.99)$ & $(1.05)$ \\
\hline \multirow[t]{2}{*}{ Immigrant * national identification very strongly } & $2.57^{*}$ & $2.48^{*}$ & $2.53^{*}$ \\
\hline & $(1.37)$ & $(1.30)$ & $(1.34)$ \\
\hline \multirow[t]{2}{*}{ Child of immigrant $*$ national identification somewhat strongly } & $2.62 * *$ & $2.53^{* *}$ & $2.57^{* *}$ \\
\hline & $(1.04)$ & $(1.00)$ & $(1.02)$ \\
\hline \multirow[t]{2}{*}{ Child of immigrant * national identification very strongly } & 1.84 & 1.85 & 1.82 \\
\hline & $(0.73)$ & $(0.73)$ & $(0.72)$ \\
\hline \multirow[t]{2}{*}{ England } & $0.64 * * *$ & $0.64 * * *$ & $0.66 * * *$ \\
\hline & $(0.09)$ & $(0.09)$ & $(0.09)$ \\
\hline \multirow[t]{2}{*}{ Germany } & $4.65 * * *$ & $4.31 * * *$ & $4.82 * * *$ \\
\hline & $(0.52)$ & $(0.47)$ & $(0.57)$ \\
\hline \multirow[t]{2}{*}{ the Netherlands } & $1.54 * * *$ & $1.34^{* *}$ & $1.59 * * *$ \\
\hline & $(0.21)$ & $(0.17)$ & $(0.22)$ \\
\hline \multirow[t]{2}{*}{ No ethnic identification (ref: identify very strongly) } & 0.94 & 0.95 & 0.94 \\
\hline & $(0.21)$ & $(0.21)$ & $(0.20)$ \\
\hline \multirow[t]{2}{*}{ Ethnic identification: not at all/not very strongly } & 1.22 & 1.20 & 1.21 \\
\hline & $(0.33)$ & $(0.33)$ & $(0.33)$ \\
\hline \multirow[t]{2}{*}{ Ethnic identification somewhat strongly } & 1.09 & 1.09 & 1.08 \\
\hline & $(0.26)$ & $(0.26)$ & $(0.25)$ \\
\hline \multirow[t]{2}{*}{ Girl } & $0.48 * * *$ & $0.49 * * *$ & $0.48 * * *$ \\
\hline & $(0.05)$ & $(0.05)$ & $(0.05)$ \\
\hline \multirow[t]{2}{*}{ Citizenship = survey country and other } & 0.76 & 0.78 & 0.77 \\
\hline & $(0.18)$ & $(0.19)$ & $(0.19)$ \\
\hline \multirow[t]{2}{*}{ Citizenship = only other country } & 0.84 & 0.84 & 0.86 \\
\hline & $(0.23)$ & $(0.23)$ & $(0.24)$ \\
\hline \multirow[t]{2}{*}{ Political discussion at home } & $2.17 * * *$ & $2.23 * * *$ & $2.18^{* * *}$ \\
\hline & $(0.10)$ & $(0.10)$ & $(0.10)$ \\
\hline \multirow[t]{2}{*}{ Mixed friendships } & $1.38^{*}$ & $1.41^{*}$ & $1.39 *$ \\
\hline & $(0.26)$ & $(0.27)$ & $(0.27)$ \\
\hline \multirow[t]{2}{*}{ Use of second language } & 1.01 & 1.01 & 1.01 \\
\hline & $(0.04)$ & $(0.04)$ & $(0.04)$ \\
\hline \multirow[t]{2}{*}{ Associationism } & 1.02 & 1.04 & 1.02 \\
\hline & $(0.04)$ & $(0.04)$ & $(0.04)$ \\
\hline Religious activities & $1.25 * * *$ & $1.25 * * *$ & $1.24 * * *$ \\
\hline & $(0.07)$ & $(0.07)$ & $(0.07)$ \\
\hline Felt discriminated rarely or more often & 0.91 & 0.91 & 0.91 \\
\hline & $(0.10)$ & $(0.10)$ & $(0.10)$ \\
\hline Africa and Middle East & 1.38 & 1.43 & 1.41 \\
\hline & $(0.32)$ & $(0.32)$ & $(0.32)$ \\
\hline Asia & $2.10^{* *}$ & $2.09 * *$ & $2.01 * *$ \\
\hline & $(0.61)$ & $(0.61)$ & $(0.58)$ \\
\hline Latin America and Caribbean & 0.93 & 1.00 & 0.93 \\
\hline & $(0.34)$ & $(0.38)$ & $(0.34)$ \\
\hline
\end{tabular}


Table A4. (Cont.) Odds ratios (robust SE) from the pooled logit model predicting the probabilities to report interest in politics of the survey country with parental information (weighted sample, listwise deletion). Source: CILS4EU data; own analysis.

\begin{tabular}{lccc}
\hline & M1 & M2 & M3 \\
\hline National identification mother somewhat strongly & & 1.12 & $(0.14$ \\
National identification mother very strongly & & $(0.19)$ & 1.25 \\
& & 1.19 & $(0.22)$ \\
Parents academics & & $(0.21)$ & $1.44^{* * *}$ \\
& & $1.42^{* * *}$ & $(0.18)$ \\
Constant & $(0.17)$ & $0.03^{* * *}$ \\
& $0.04^{* * *}$ & $0.03^{* * *}$ & $(0.01)$ \\
\hline Observations & $(0.01)$ & $(0.01)$ & 7,700 \\
\hline AIC & 7,700 & 7,700 & 678364.9 \\
Log pseudolikelihood & 678831.7 & 680908.6 & -339152.44 \\
\hline
\end{tabular}

Note: Robust se (eform) in parentheses; ${ }^{* * *} p<0.01,{ }^{* *} p<0.05,{ }^{*} p<0.1$.

Table A5. Odds ratio (SE) predicting political interest among respondents with interaction effects (weighted sample, listwise deletion). Source: CILS4EU data; own analysis.

\begin{tabular}{|c|c|c|}
\hline & M1 & $\mathrm{M} 2$ \\
\hline \multirow[t]{2}{*}{ Immigrant } & 0.77 & $0.50^{*}$ \\
\hline & $(0.24)$ & $(0.19)$ \\
\hline \multirow[t]{2}{*}{ Child of immigrant(s) } & 0.78 & $0.45^{* * *}$ \\
\hline & $(0.19)$ & $(0.13)$ \\
\hline \multirow[t]{2}{*}{ National identification (somewhat strongly, ref: not at all/not very) } & 0.99 & 0.88 \\
\hline & $(0.20)$ & $(0.18)$ \\
\hline \multirow[t]{2}{*}{ National identification (strongly) } & 1.11 & 1.00 \\
\hline & $(0.21)$ & $(0.19)$ \\
\hline \multirow[t]{2}{*}{ Immigrant * national identification somewhat strongly } & 1.63 & 1.75 \\
\hline & $(0.61)$ & $(0.64)$ \\
\hline \multirow[t]{2}{*}{ Immigrant * national identification very strongly } & $2.83^{* * *}$ & $2.34 * *$ \\
\hline & $(1.12)$ & $(1.00)$ \\
\hline \multirow[t]{2}{*}{ Child of immigrant * national identification somewhat strongly } & $2.11^{* * *}$ & $2.19 * *$ \\
\hline & $(0.59)$ & $(0.67)$ \\
\hline \multirow[t]{2}{*}{ Child of immigrant * national identification very strongly } & 1.46 & 1.56 \\
\hline & $(0.41)$ & $(0.50)$ \\
\hline \multirow[t]{2}{*}{ England } & $0.72 * * *$ & $0.58 * * *$ \\
\hline & $(0.06)$ & $(0.06)$ \\
\hline \multirow[t]{2}{*}{ Germany } & $4.09 * * *$ & $4.43 * * *$ \\
\hline & $(0.32)$ & $(0.40)$ \\
\hline \multirow[t]{2}{*}{ the Netherlands } & $1.50 * * *$ & $1.38 * * *$ \\
\hline & $(0.14)$ & $(0.15)$ \\
\hline \multirow[t]{2}{*}{ No ethnic identification (ref: identify very strongly) } & & 1.03 \\
\hline & & $(0.18)$ \\
\hline \multirow[t]{2}{*}{ Ethnic identification: not at all/not very strongly } & & 1.23 \\
\hline & & $(0.26)$ \\
\hline \multirow[t]{2}{*}{ Ethnic identification somewhat strongly } & & 1.16 \\
\hline & & $(0.21)$ \\
\hline \multirow[t]{2}{*}{ Girl } & & $0.55 * * *$ \\
\hline & & $(0.05)$ \\
\hline \multirow[t]{2}{*}{ Citizenship = survey country and other } & & 0.82 \\
\hline & & $(0.15)$ \\
\hline \multirow[t]{2}{*}{ Citizenship $=$ only other country } & & 0.84 \\
\hline & & $(0.16)$ \\
\hline
\end{tabular}


Table A5. (Cont.) Odds ratio (SE) predicting political interest among respondents with interaction effects (weighted sample, listwise deletion). Source: CILS4EU data; own analysis.

\begin{tabular}{|c|c|c|}
\hline & M1 & M2 \\
\hline \multirow[t]{2}{*}{ Political discussion at home } & & $2.28 * * *$ \\
\hline & & $(0.09)$ \\
\hline \multirow[t]{2}{*}{ Mixed friendships } & & $1.36 * *$ \\
\hline & & $(0.20)$ \\
\hline \multirow[t]{2}{*}{ Use of second language } & & 0.10 \\
\hline & & $(0.03)$ \\
\hline \multirow[t]{2}{*}{ Associationism } & & $1.08 * *$ \\
\hline & & $(0.03)$ \\
\hline \multirow[t]{2}{*}{ Religious activities } & & $1.23 * * *$ \\
\hline & & $(0.05)$ \\
\hline \multirow[t]{2}{*}{ Felt discriminated rarely or more often } & & 1.00 \\
\hline & & $(0.09)$ \\
\hline \multirow[t]{2}{*}{ Africa and Middle East } & & $1.81^{* * *}$ \\
\hline & & $(0.33)$ \\
\hline \multirow[t]{2}{*}{ Asia } & & $1.68 * * *$ \\
\hline & & $(0.33)$ \\
\hline \multirow[t]{2}{*}{ Latin America and Caribbean } & & 1.231 \\
\hline & & $(0.35)$ \\
\hline \multirow[t]{2}{*}{ Constant } & $0.42 * * *$ & $0.03 * * *$ \\
\hline & $(0.08)$ & $(0.01)$ \\
\hline Observations & 11,747 & 11,747 \\
\hline AIC & 1146178 & 960698.1 \\
\hline Log pseudolikelihood & -573077.17 & -480322.03 \\
\hline
\end{tabular}

Note: Robust se (eform) in parentheses; ${ }^{* * *} p<0.01,{ }^{* *} p<0.05,{ }^{*} p<0.1$.

Table A6. Odds ratio (SE) predicting political interest among individuals with an immigrant background (weighted sample, listwise deletion). Source: CILS4EU data; own analysis.

\begin{tabular}{|c|c|c|c|}
\hline & M1 & M2 & M3 \\
\hline \multirow[t]{2}{*}{ Immigrant } & 0.87 & 0.94 & 1.06 \\
\hline & $(0.13)$ & $(0.14)$ & $(0.17)$ \\
\hline \multirow[t]{2}{*}{ National identification (somewhat strongly, ref: not at all/not very) } & & $1.63^{* * *}$ & $1.60 * * *$ \\
\hline & & $(0.26)$ & $(0.28)$ \\
\hline \multirow[t]{2}{*}{ National identification (strongly) } & & $1.64 * * *$ & $1.46^{*}$ \\
\hline & & $(0.28)$ & $(0.30)$ \\
\hline \multirow[t]{2}{*}{ England } & $0.64 * * *$ & $0.63 * * *$ & $0.40 * * *$ \\
\hline & $(0.08)$ & $(0.08)$ & $(0.07)$ \\
\hline \multirow[t]{2}{*}{ Germany } & $2.26 * * *$ & $2.36 * * *$ & $2.55^{* * *}$ \\
\hline & $(0.28)$ & $(0.30)$ & $(0.39)$ \\
\hline \multirow[t]{2}{*}{ the Netherlands } & $2.45^{* * *}$ & $2.34 * * *$ & $2.12 * * *$ \\
\hline & $(0.47)$ & $(0.45)$ & $(0.44)$ \\
\hline \multirow[t]{2}{*}{ No ethnic identification (ref: identify very strongly) } & & & 1.09 \\
\hline & & & $(0.20)$ \\
\hline \multirow[t]{2}{*}{ Ethnic identification: not at all/not very strongly } & & & 0.82 \\
\hline & & & $(0.22)$ \\
\hline \multirow[t]{2}{*}{ Ethnic identification somewhat strongly } & & & 0.90 \\
\hline & & & $(0.16)$ \\
\hline \multirow[t]{2}{*}{ Girl } & & & $0.58^{* * *}$ \\
\hline & & & $(0.08)$ \\
\hline \multirow[t]{2}{*}{ Citizenship $=$ survey country and other } & & & 1.06 \\
\hline & & & $(0.20)$ \\
\hline
\end{tabular}


Table A6. (Cont.) Odds ratio (SE) predicting political interest among individuals with an immigrant background (weighted sample, listwise deletion). Source: CILS4EU data; own analysis.

\begin{tabular}{|c|c|c|c|}
\hline & M1 & M2 & M3 \\
\hline Citizenship $=$ only other country & & & $\begin{array}{c}1.08 \\
(0.20)\end{array}$ \\
\hline Political discussion at home & & & $\begin{array}{l}1.88^{* * *} \\
(0.10)\end{array}$ \\
\hline Mixed friendships & & & $\begin{array}{l}1.62^{* * *} \\
(0.25)\end{array}$ \\
\hline Use of second language & & & $\begin{array}{c}1.00 \\
(0.03)\end{array}$ \\
\hline Associationism & & & $\begin{array}{c}1.06 \\
(0.05)\end{array}$ \\
\hline Religious activities & & & $\begin{array}{l}1.30 * * * \\
(0.08)\end{array}$ \\
\hline Felt discriminated rarely or more often & & & $\begin{array}{l}0.95 \\
(0.12)\end{array}$ \\
\hline Africa and Middle East & & & $\begin{array}{l}1.70^{* * *} \\
(0.29)\end{array}$ \\
\hline Asia & & & $\begin{array}{c}1.58^{* *} \\
(0.31)\end{array}$ \\
\hline Latin America and Caribbean & & & $\begin{array}{c}1.06 \\
(0.30)\end{array}$ \\
\hline Constant & $\begin{array}{l}0.70 * * * \\
(0.06)\end{array}$ & $\begin{array}{l}0.47^{* * *} \\
(0.07)\end{array}$ & $\begin{array}{l}0.03^{* * *} \\
(0.01)\end{array}$ \\
\hline Observations & 4,437 & 4,437 & 4,437 \\
\hline $\begin{array}{l}\text { AIC } \\
\text { Log pseudolikelihood }\end{array}$ & $\begin{array}{c}273654.9 \\
-136822.47\end{array}$ & $\begin{array}{c}271637.5 \\
-135811.74\end{array}$ & $\begin{array}{c}235569.9 \\
-117762.97\end{array}$ \\
\hline
\end{tabular}

Note: Robust se (eform) in parentheses; ${ }^{* * *} p<0.01,{ }^{* *} p<0.05, * p<0.1$.

Table A7. Odds ratio (SE) predicting political interest among respondents (weighted sample, listwise deletion) with alternative immigrant status coding. source: CILS4EU; own analysis.

\begin{tabular}{|c|c|c|c|}
\hline & M1 & M2 & M3 \\
\hline \multirow[t]{2}{*}{ Immigrants } & 1.11 & 1.27 & 0.83 \\
\hline & $(0.16)$ & $(0.19)$ & $(0.22)$ \\
\hline \multirow[t]{2}{*}{ Immigrant offspring } & $1.22 * *$ & $1.30 * * *$ & 0.77 \\
\hline & $(0.10)$ & $(0.11)$ & $(0.16)$ \\
\hline \multirow[t]{2}{*}{ National identification (somewhat strongly, ref: not at all/not very) } & & $1.39 * *$ & 1.23 \\
\hline & & $(0.19)$ & $(0.18)$ \\
\hline \multirow[t]{2}{*}{ National identification (strongly) } & & $1.48 * * *$ & $1.33^{* *}$ \\
\hline & & $(0.20)$ & $(0.19)$ \\
\hline \multirow[t]{2}{*}{ England } & $0.71 * * *$ & $0.72 * * *$ & $0.58 * * *$ \\
\hline & $(0.06)$ & $(0.06)$ & $(0.06)$ \\
\hline \multirow[t]{2}{*}{ Germany } & $4.00 * * *$ & $4.07 * * *$ & $4.46 * * *$ \\
\hline & $(0.31)$ & $(0.32)$ & $(0.40)$ \\
\hline \multirow[t]{2}{*}{ the Netherlands } & $1.49 * * *$ & $1.49 * * *$ & $1.38 * * *$ \\
\hline & $(0.14)$ & $(0.14)$ & $(0.15)$ \\
\hline \multirow[t]{2}{*}{ No ethnic identification (ref: identify very strongly) } & & & 1.05 \\
\hline & & & $(0.19)$ \\
\hline \multirow[t]{2}{*}{ Ethnic identification: not at all/not very strongly } & & & 1.22 \\
\hline & & & $(0.26)$ \\
\hline \multirow[t]{2}{*}{ Ethnic identification somewhat strongly } & & & 1.16 \\
\hline & & & $(0.21)$ \\
\hline
\end{tabular}


Table A7. (Cont.) Odds ratio (SE) predicting political interest among respondents (weighted sample, listwise deletion) with alternative immigrant status coding. source: CILS4EU; own analysis.

\begin{tabular}{|c|c|c|c|}
\hline & M1 & M2 & M3 \\
\hline Girl & & & $\begin{array}{l}0.54^{* * *} \\
(0.05)\end{array}$ \\
\hline Citizenship = survey country and other & & & $\begin{array}{l}0.78 \\
(0.14)\end{array}$ \\
\hline Citizenship $=$ only other country & & & $\begin{array}{c}0.78 \\
(0.15)\end{array}$ \\
\hline Political discussion at home & & & $\begin{array}{l}2.27^{* * *} \\
(0.09)\end{array}$ \\
\hline Mixed friendships & & & $\begin{array}{l}1.44^{* *} \\
(0.22)\end{array}$ \\
\hline Use of second language & & & $\begin{array}{c}1.00 \\
(0.03)\end{array}$ \\
\hline Associationism & & & $\begin{array}{l}1.08^{* *} \\
(0.03)\end{array}$ \\
\hline Religious activities & & & $\begin{array}{l}1.22^{* * *} \\
(0.05)\end{array}$ \\
\hline Felt discriminated rarely or more often & & & $\begin{array}{c}1.01 \\
(0.09)\end{array}$ \\
\hline Africa and Middle East & & & $\begin{array}{l}1.78^{* * *} \\
(0.31)\end{array}$ \\
\hline Asia & & & $\begin{array}{l}1.75^{* * *} \\
(0.32)\end{array}$ \\
\hline Latin America and Caribbean & & & $\begin{array}{c}1.23 \\
(0.32)\end{array}$ \\
\hline Constant & $\begin{array}{l}0.45^{* * *} \\
(0.02)\end{array}$ & $\begin{array}{l}0.31^{* * *} \\
(0.04)\end{array}$ & $\begin{array}{l}0.02^{* * *} \\
(0.01)\end{array}$ \\
\hline Observations & 11,612 & 11,612 & 11,612 \\
\hline AIC & 1136762 & 1134558 & 951725.8 \\
\hline Log pseudolikelihood & -568375.05 & -567270.92 & -475839.89 \\
\hline
\end{tabular}

Note: Robust se (eform) in parentheses; ${ }^{* *} p<0.01,{ }^{* *} p<0.05,{ }^{*} p<0.10$.

Table A8. Odds ratio (SE) predicting political interest among respondents (weighted sample, listwise deletion) with alternative immigrant status coding. Source: CILS4EU data; own analysis.

\begin{tabular}{|c|c|c|}
\hline & M1 & M2 \\
\hline \multirow[t]{2}{*}{ Immigrants } & 0.75 & $0.50 *$ \\
\hline & $(0.24)$ & $(0.20)$ \\
\hline \multirow[t]{2}{*}{ Immigrant offspring } & 0.76 & $0.47^{* *}$ \\
\hline & $(0.19)$ & $(0.15)$ \\
\hline \multirow[t]{2}{*}{ National identification (somewhat strongly, ref: not at all/not very) } & 0.94 & 0.85 \\
\hline & $(0.20)$ & $(0.19)$ \\
\hline \multirow[t]{2}{*}{ National identification (strongly) } & 1.07 & 0.97 \\
\hline & $(0.22)$ & $(0.20)$ \\
\hline \multirow[t]{2}{*}{ Immigrant * national identification somewhat strongly } & 1.71 & 1.79 \\
\hline & $(0.66)$ & $(0.67)$ \\
\hline \multirow[t]{2}{*}{ Immigrant * national identification very strongly } & $2.92 * * *$ & $2.37^{* *}$ \\
\hline & $(1.18)$ & $(1.03)$ \\
\hline \multirow[t]{2}{*}{ Immigrant offspring * national identification somewhat strongly } & $2.11 * * *$ & $2.06 * *$ \\
\hline & $(0.60)$ & $(0.63)$ \\
\hline \multirow[t]{2}{*}{ Immigrant offspring * national identification very strongly } & 1.56 & 1.61 \\
\hline & $(0.44)$ & $(0.50)$ \\
\hline
\end{tabular}


Table A8. (Cont.) Odds ratio (SE) predicting political interest among respondents (weighted sample, listwise deletion) with alternative immigrant status coding. Source: CILS4EU data; own analysis.

\begin{tabular}{|c|c|c|}
\hline & M1 & M2 \\
\hline \multirow[t]{2}{*}{ England } & $0.72 * * *$ & $0.58 * * *$ \\
\hline & $(0.06)$ & $(0.06)$ \\
\hline \multirow[t]{2}{*}{ Germany } & $4.12 * * *$ & $4.47^{* * *}$ \\
\hline & $(0.32)$ & $(0.41)$ \\
\hline \multirow[t]{2}{*}{ the Netherlands } & $1.50 * * *$ & $1.38^{* * *}$ \\
\hline & $(0.14)$ & $(0.15)$ \\
\hline \multirow[t]{2}{*}{ No ethnic identification (ref: identify very strongly) } & & 1.07 \\
\hline & & $(0.19)$ \\
\hline \multirow[t]{2}{*}{ Ethnic identification: not at all/not very strongly } & & 1.19 \\
\hline & & $(0.26)$ \\
\hline \multirow[t]{2}{*}{ Ethnic identification somewhat strongly } & & 1.15 \\
\hline & & $(0.20)$ \\
\hline \multirow[t]{2}{*}{ Girl } & & $0.54 * * *$ \\
\hline & & $(0.05)$ \\
\hline \multirow[t]{2}{*}{ Citizenship $=$ survey country and other } & & 0.81 \\
\hline & & $(0.15)$ \\
\hline \multirow[t]{2}{*}{ Citizenship $=$ only other country } & & 0.83 \\
\hline & & $(0.16)$ \\
\hline \multirow[t]{2}{*}{ Political discussion at home } & & $2.26 * * *$ \\
\hline & & $(0.09)$ \\
\hline \multirow[t]{2}{*}{ Mixed friendships } & & $1.38^{* *}$ \\
\hline & & $(0.21)$ \\
\hline \multirow[t]{2}{*}{ Use of second language } & & 1.00 \\
\hline & & $(0.03)$ \\
\hline \multirow[t]{2}{*}{ Associationism } & & $1.08 * *$ \\
\hline & & $(0.03)$ \\
\hline \multirow[t]{2}{*}{ Religious activities } & & $1.23^{* * *}$ \\
\hline & & $(0.05)$ \\
\hline \multirow[t]{2}{*}{ Felt discriminated rarely or more often } & & 1.01 \\
\hline & & $(0.09)$ \\
\hline \multirow[t]{2}{*}{ Africa and Middle East } & & $1.77^{* * *}$ \\
\hline & & $(0.31)$ \\
\hline \multirow[t]{2}{*}{ Asia } & & $1.69 * * *$ \\
\hline & & $(0.31)$ \\
\hline \multirow[t]{2}{*}{ Latin America and Caribbean } & & 1.21 \\
\hline & & $(0.32)$ \\
\hline \multirow[t]{2}{*}{ Constant } & $0.43 * * *$ & $0.03 * * *$ \\
\hline & $(0.09)$ & $(0.01)$ \\
\hline Observations & 11,612 & 11,612 \\
\hline AIC & 1132060 & 950205.9 \\
\hline Log pseudolikelihood & -566018.23 & -475075.93 \\
\hline
\end{tabular}

Note: Robust se (eform) in parentheses; ${ }^{* * *} p<0.01,{ }^{* *} p<0.05,{ }^{*} p<0.1$. 


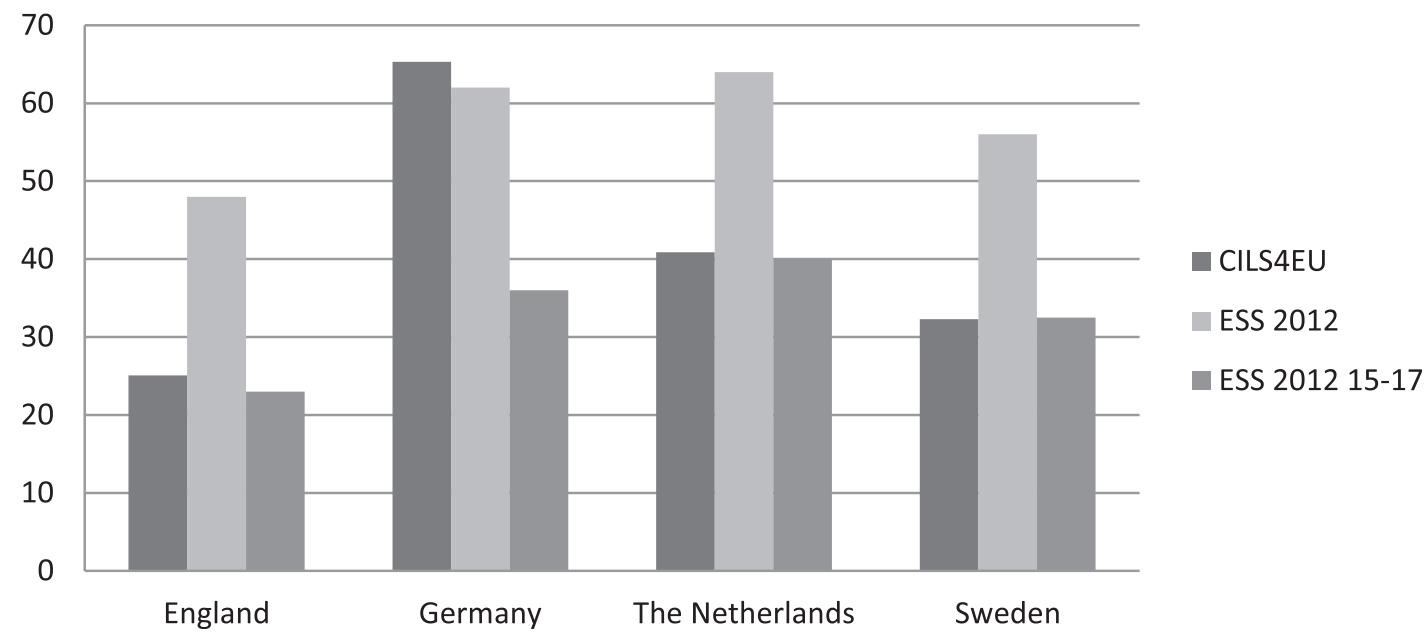

Figure A1. Politically interested respondents in survey country (percentage). Comparison of political interest between European Social Survey data from 2012 and the CILS4EU data; own analysis. Note: In the ESS the United Kingdom is studied and not England.
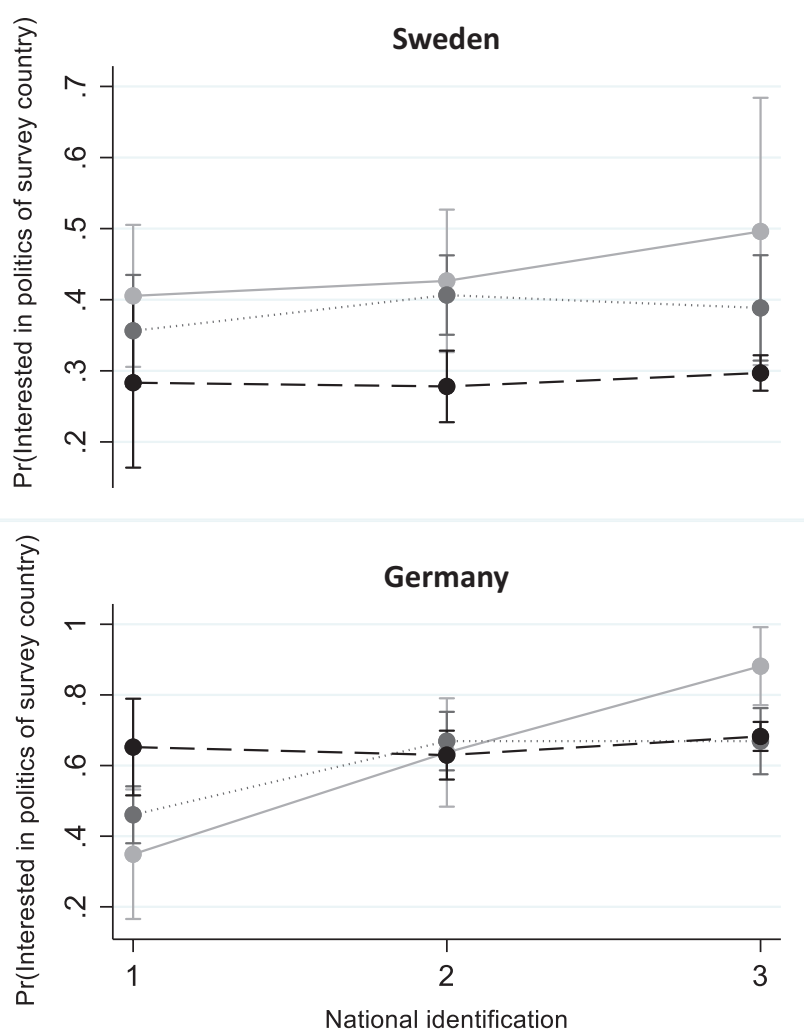

The Netherlands

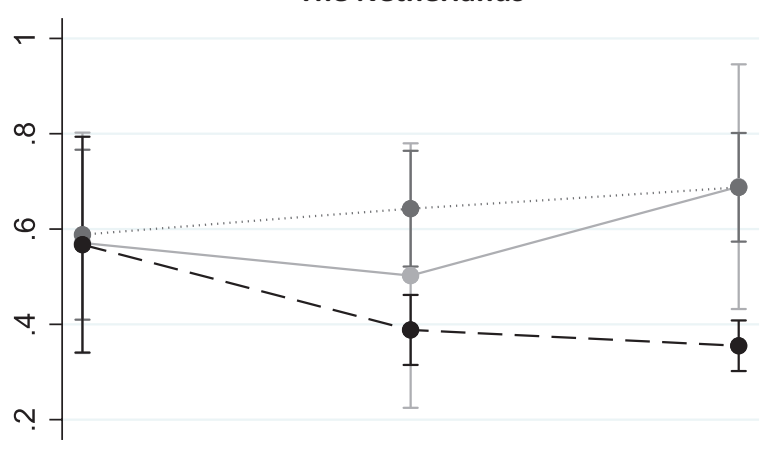

England

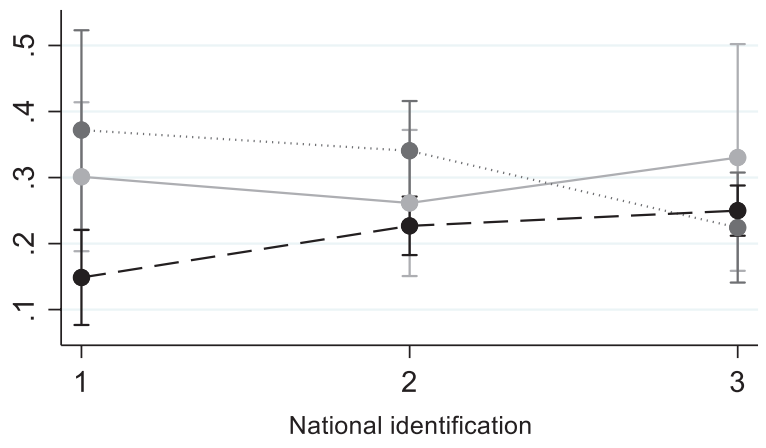

$$
\text { Immigrant } \quad \text { Child of immigrant }- \text { - Other/Native }
$$

Figure A2. Predicted probabilities of being interested in the politics of the survey country according to strength of national identification and immigrant status. Source: CILS4EU data; own analysis. 